\section{Fewer Herring}

The North Sea Fisheries Committee has asked the British Government to ban herring fishing within the 12 mile limit in an area of the North Sea between the River Tees and Flamborough Head. The ban, if implemented, would operate during the months of August and September, the spawning time of the herring, for an experimental period of 5 years. The Government cannot, however, impose the ban without the agreement of the Netherlands and West Germany who have traditional rights to fish in this area. There is to be a meeting in mid-September between representatives of all three governments to discuss the question.

The trouble seems to revolve around the decline in the populations of the herring in different parts of the North Sea. The precise causes of the decline are disputed, but overfishing has probably been an important factor. Some populations-for example, those of East Anglia-have been almost wiped out, and it is feared that the middle North Sea fisheries might go the same way. Fishermen in the Whitby and Scarborough areas are worried because of their decreased landings of herring, although overall catches are up because of the increased amount of fishing, particularly by the Germans and the Dutch. The Dutch and German fishermen use a trawling method for catching herring in which the trawls are swept along near the sea bed where the herring are concentrated for spawning. This is probably more successful than the drift and ring nets used by British fishermen although there are uncertainties about this. So far, not many British fishermen have adopted the trawling method.

In theory, an answer to the problem might be a ban on trawling in the spawning period. In practice, however, this would discriminate unfairly between different methods of fishing and fishermen. If there is to be a ban, therefore, it will have to be a comprehensive one within the 12 mile limit. It could not be put into effect before next year, because this year the herring season has already started.

All stocks of North Sea fish are being reduced by overfishing, but while cod, haddock and plaice are protected by international regulations, there are no such regulations for herring. There seems, therefore, to be a case for an experimental ban in the area concerned, one of the spawning areas of the herring, but it is unlikely to please everyone. The British proposal might well be unacceptable to the Dutch and the Germans. Last year a proposal to ban herring fishing in the southern part of the North Sea was made at a meeting of the North East Atlantic Fisheries Commission, but no agreement was reached.

\section{New Colours for Cables}

The Home Office has decided to make regulations on the colour coding of the three-core cables attached to domestic appliances, to bring British practice into line with the rules agreed by the Common Market countries two years ago. No date has been fixed for the changeover, but the aim is January 1, 1970, some six months after the date fixed by the Common Market (June 15, 1969) after which only the new code will be allowed. The new code, which has been recommended by the International Commission on Rules for the Approval of Electrical Equipment, specifies brown for the live core, light blue for the neutral and a combination of green and yellow for the earth core. The present British Standard code of red for the live core, black for the neutral and green for the earth will be permitted until the changeover date.

As manufacturers in the Common Market are already using the new code, it is important that there should be a wide programme of publicity before domestic equipment from Europe carrying the new colours starts to appear in Britain. This is especially important as the diversity of plug types in Britain means that the practice is usually to leave the fitting of plugs to domestic equipment to the customer. While the international standardization of the coding of cables attached to domestic appliances is clearly necessary, the dangers inherent in the changeover cannot be over-emphasized. The aim must be to change to the new system as rapidly as possible, with an extensive campaign to prepare and protect the public.

\section{How to Prevent Accidents}

Six years after it began life as a working party set up by the Royal College of Surgeons, the Medical Commission on Accident Prevention is receiving financial support from more than forty individuals and organizations, including various academic bodies in medicine, surgery and gynaecology. The fourth annual report reveals that the commission is actively furthering its aims of studying the epidemiology of accidents and advising on methods of prevention and rescue.

A research grant of $£ 5,000$ from the Worshipful Company of Drapers enabled the commission to extend its support for physiological research to studies of outdoor activities, with particular reference to runners, canoeists and potholers, being carried out at Oxford by Dr J. Corbett and Dr R. H. Johnson. Dr Walter Somerville's project, concerned with cardiovascular changes in drivers when driving in the traffic of Central London, is now at the stage of the preliminary report. One-third of a group of presumably healthy drivers experienced a greatly increased heart rate, and a smaller number showed marked changes on the electrocardiogram. Most of a group of drivers with a history of coronary disease experienced no change, but in some cases there were irregularities, sometimes angina pectoris, and in one case heart failure. Some profes. sional racing drivers had a very fast heart rate just before the start of a race. Future work is planned to find out whether drugs can be used to correct such abnormalities without risk.

An enquiry into accidents to children less than five years old has shown a possible decrease in the number of burns and scalds, but more cases of poisoning, especially caused by medicines. Many physical and psychological problems arise in areas of multistorey housing developments, and the report points out that play facilities should be receiving much more attention from architects and local authorities. A report on the investigation into industrial hand injuries draws attention to the poor standard of first aid - eight per cent of a sample of 579 injured people had received no first aid from trained personnel. There was a high incidence of hand injuries in machine accidents and a significant failure to use the protective devices fitted to machines. There also seems to be a need for better discipline in the wearing and design of protective clothing. 